https://www.journal-imab-bg.org

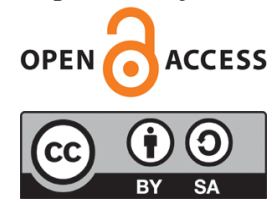

Case report

\title{
INTRACAVITY TOOTH BLEACHING IN THE AESTHETIC ZONE OF MAXILLA USING CARBAMIDE PEROXIDE GEL - CASE REPORT
}

\author{
Irena Georgieva \\ Department of Periodontology and Dental Implantology Dental Faculty, Medical \\ University-Varna, Bulgaria.
}

\begin{abstract}
:
Introduction: The success of intracavity bleaching in nonvital teeth is related to the ability of penetration or diffusion of the bleaching agent into dentin and enamel tissues. This manipulation can be done with some active ingredients as carbamide peroxide, hydrogen peroxide or sodium perborate. Some of the most popular techniques that can be used for this purpose are inside/outside bleaching technique, in-office bleaching, the walking bleaching technique, thermocatalytic technique. Òhe carbamide peroxide gel is used in different concentrations. Recently this whitening agent is more recommended for use in intracoronal bleaching.
\end{abstract}

Purpose: The aim of this case report is to show the quick effect of intracavity bleaching of the discolorated crown of nonvital central incisor, using a $45 \%$ carbamide peroxide gel.

Material and methods: A modified walking bleaching method is presented in bleaching of a single discolored nonvital central incisor (11).

Results: The color of the tooth was changed to the aesthetic demands of the patient after 3 intracavity applications of bleaching agent.

Conclusion: Carbamide peroxide gel is a secure option for fast and satisfying intracavity bleaching.

Keywords: intracavity bleaching, nonvital teeth, carbamide peroxide

\section{INTRODUCTION:}

Intracavity dental bleaching techniques have been used for many years, as for this purpose the bleaching of nonvital teeth can be done with one of these active ingredients: carbamide peroxide, hydrogen peroxide or sodium perborate. The most popular techniques for intracavity bleaching are inside and outside combined bleaching technique, in-office bleaching, the walking bleaching technique, thermocatalytic technique. [1]

The reason for the discoloration of the dental tissues is very important for the effect of treatment outcome. [2] It can be divided into intrinsic, extrinsic pigmentation or a combination of both. [3] The intrinsic discolorations àre deep pigmentations that involve the thickness of the tooth substrates, the enamel and the dentin. In intracavity bleach- ing, the dentin is the substrate that is directly exposed to the action of the bleaching agent. The success of the dental bleaching treatment is related to the ability of penetration or diffusion of the peroxide gel into enamel and dentin. [4]

Hydrogen peroxide is used as a bleaching agent at concentration varying from 5\%-35\%. Carbamide peroxide $\left[\mathrm{CO}\left(\mathrm{NH}_{2}\right) 2 \mathrm{H}_{2} \mathrm{O}_{2}\right]$ is formed by urea and hydrogen peroxide and also used in different concentrations from 10-45\%. It contains hydrogen peroxide: carbamide peroxide at a ratio of $1: 3$. The whitening power of carbamide peroxide is released of approximately $50 \%$ in the first two hours, and its action continues for another six hours. [5] Recently, this whitening agent is more recommended for use in intracoronal bleaching. [6]

The use of a walking technique with a high concentration of whitening agent hides a risk for cervical root resorption and that is why it is important the patient be informed about the possible complications and the risk of recurrent discoloration. [7] But it is reported that the walking bleach technique in most of the cases does not cause cervical resorption, even 1 year after bleaching. [8] One of the most significant predisposing factors for cervical root resorption is the combination of bleaching treatment of nonvital tooth and history of trauma. [9]

The aim of this case report is to show the quick effect of intracavity bleaching of the discoloured hard dental tissues (enamel and dentin) in the aesthetic zone of upper jaw, using a carbamide peroxide gel and the long-lasting stability of bleaching.

\section{CASE DESCRIPTION:}

A patient is a 38 years old woman. Non-smoker. No systemic diseases. No medicaments intake. She came with aesthetic complaints about the discoloration of her central incisor (tooth 11) after root canal treatment. There is no pain or mobility of the tooth. The patient does not report about trauma in the aesthetic zone of upper jaw.

During the intraoral examination, the shade of tooth color is determined due to the Vita shade guide. The periodontal tissues around the tooth are healthy.

Treatment: A modified walking bleach method using $45 \%$ carbamide peroxide gel as a bleaching agent is presented. It minimizes the risk of cervical root resorption because treatment time is reduced. 
An endodontic access cavity on the palatal surface of tooth \#11 is prepared. It is important to make access to the mesial and distal pulp horns in the pulp cavity because they can contain necrotic pulpal remnants, which can lead to discoloration. The remnants of restorative materials and necrotic pulp tissue are completely removed. The discolored dentin tissues are cleaned and the root canal filling material is råmoved at a level 1-2 mm apical to cemento-enamel junction (CEJ) and sealed with flowable resin composite at the level of CEJ. Additional cleaning with sodium hypochlorite of the access cavity is also done. The dentin is cleaned with alcohol before application of the bleaching agent. À carbamide peroxide gel is applied in the endodontic cavity and is left in the tooth so that it can function as a walking bleaching agent until the next visit. The tooth is closed with a bonded temporary filling to seal the access cavity. The application of the gel must be repeated for optimum result. The bleaching gel is applied every day in a period of 3 days. In this clinical case, 3 sessions of application of carbamide peroxide gel, $45 \%$ were required until a favorable change of color is observed that satisfied the aesthetic expectations of the patient.

As resin composites cannot be bleached, due to bleaching techniques, the existing restoration on the mesial surface of tooth \#11 is replaced at the end of bleaching treatment to improve color matching and to get optimal results.

\section{Pic. 1. Tooth 11 - initial state}

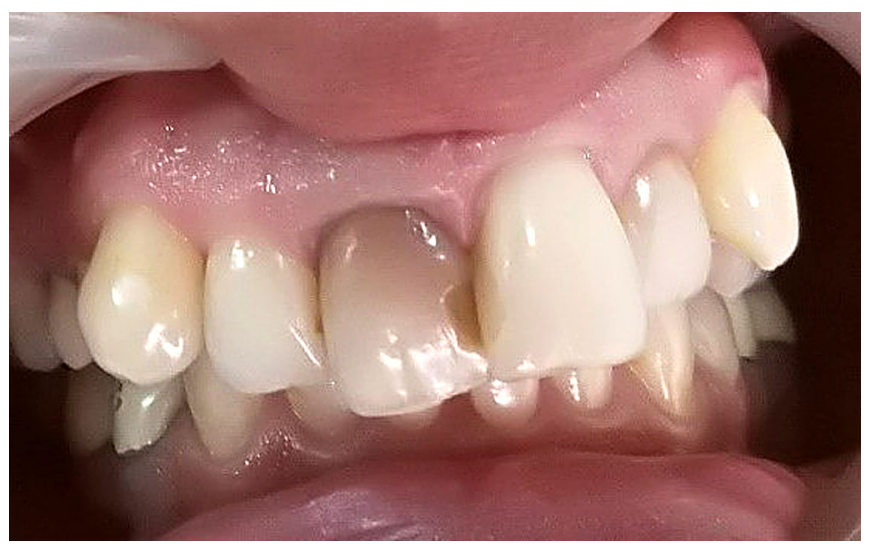

Pic. 2. The same tooth after 1 st bleaching session

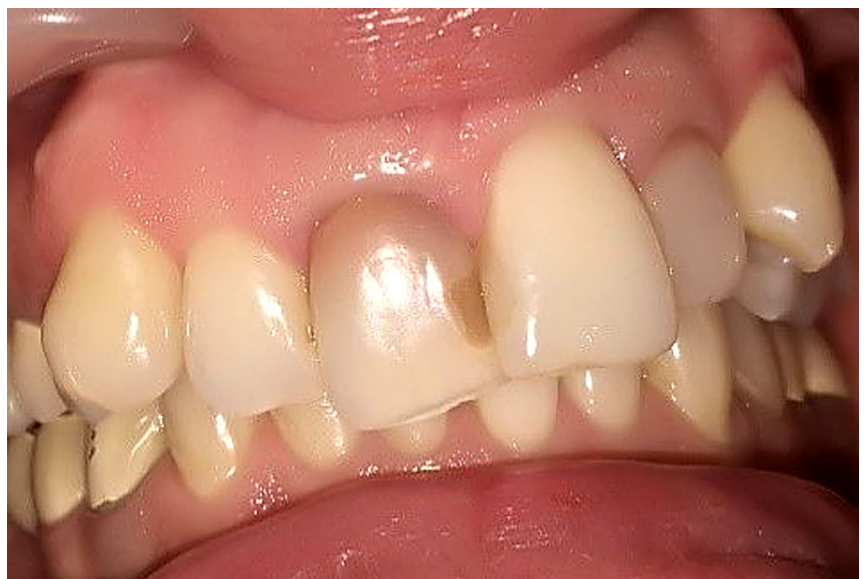

Pic. 3. The same tooth after 2 nd bleaching session

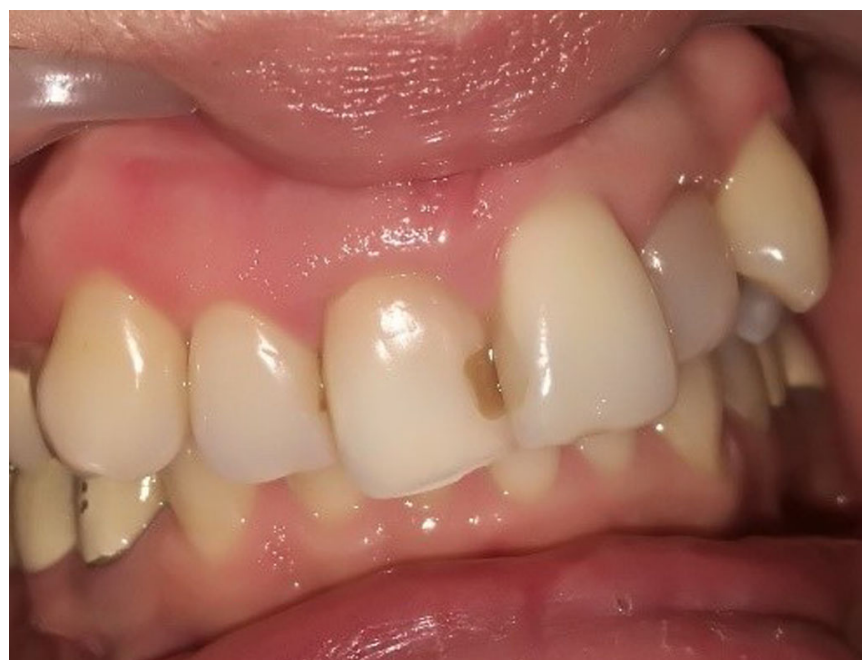

Pic. 4. The same tooth after $3^{\text {rd }}$ bleaching session

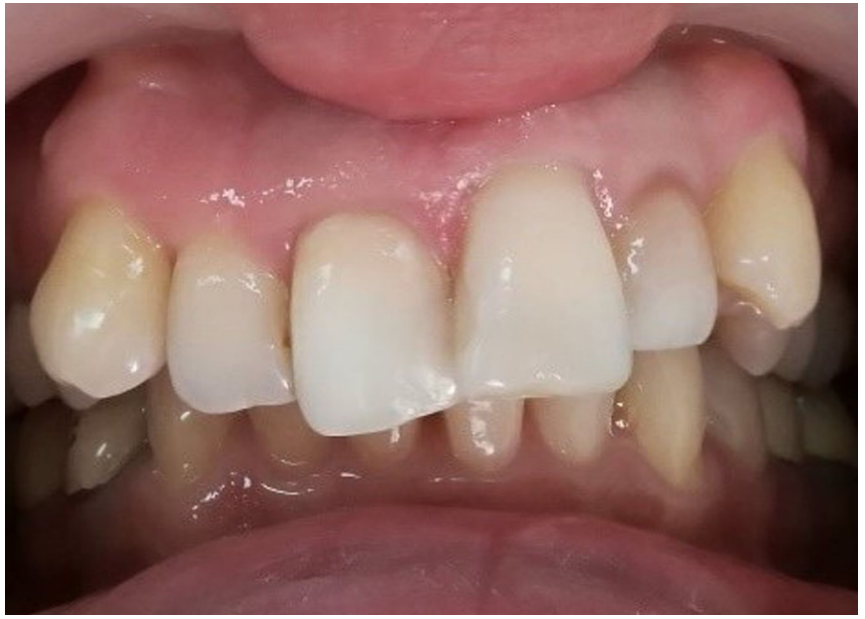

The restoration on the mesial surface of the tooth is replaced with that shade of material that matched to the whitened tooth.

\section{RESULTS:}

The color of the tooth was changed from shade $\mathrm{C} 4$ to shade A3 after 3 applications of carbamide peroxide gel $45 \%$ in the cavity of the tooth crown.

Pic. 5. Before bleaching treatment

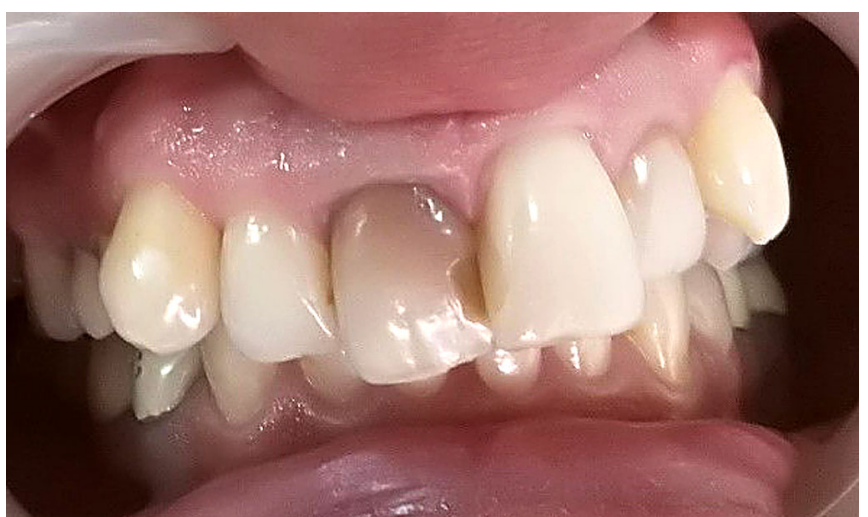


Pic. 6. After bleaching treatment

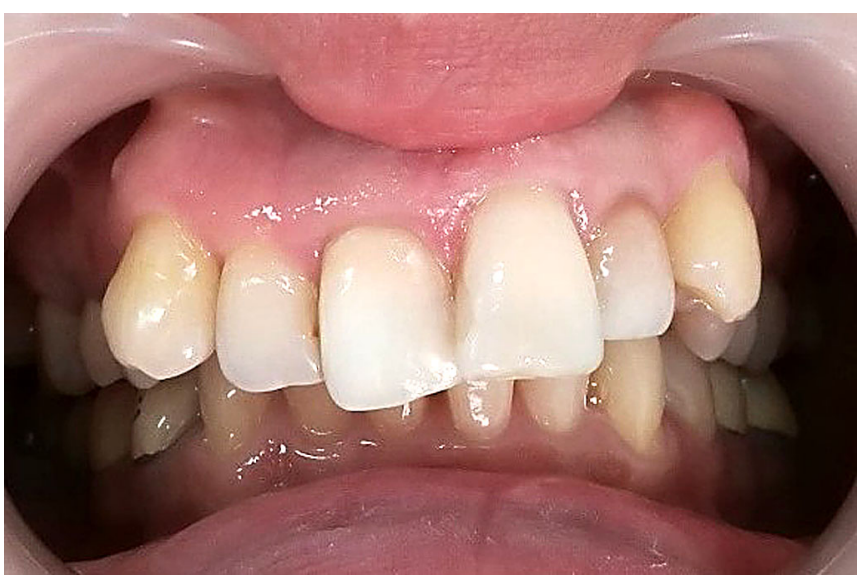

\section{DISCUSSION:}

The results of some studies showed that if discoloration of teeth is due to trauma or pulp necrosis, bleaching is successful in about $95 \%$ of the cases in comparison with the lower success rate of bleaching of teeth, discolored due to drugs or restoration failure [8] Discoloration caused by root canal medicaments and root canal sealants is difficult to bleach. [10] There is evidence that prolonged bleaching with carbamide peroxide affects the enamel and the dentin and reaches the desired results. [11,12] One year after bleaching treatment, it is recommended a follow-up radiograph of the treated tooth to be done to diagnose possible cervical resorption. [13]

In this case, the color of the discolorated central incisor is effectively changed in a period of 3 days after 3 applications of carbamide peroxide gel $45 \%$. Intracavity bleaching of endodontically treated teeth is an alternative conservative method of treatment to a more invasive esthetic treatment such as placement of crowns or veneers.

\section{CONCLUSION:}

The carbamide peroxide gel is a secure option for fast and satisfying intracavity bleaching of nonvital teeth, that preserves the tooth structures healthy.

\section{ABBREVIATIONS:}

CEJ - cemento-enamel junction

\section{REFERENCES:}

1. Zimmerli B, Jeger F, Lussi A. Bleaching of nonvital teeth. A clinically relevant literaturereview. Schweiz Monatsschr Zahnmed. 2010; 120(4): 306-20 [PubMed]

2. Dubal R, Porter RWJ. An update on discoloured teeth and bleaching part 1: the aetiology and diagnosis of discoloured teeth. Dental Update. 2018 Jul 2;45(7):601-8. [Crossref]

3. Watts A, Addy M. Tooth discoloration and staining: a review of the literature. Br Dent J. 2001 Mar 24; 190(6):309-16. [PubMed]

4. Bharti R, Wadhwani K. Spectrophotometric evaluation of peroxide penetration into the pulp chamber from whitening strips and gel: An in vitro study. J Conserv Dent. 2013 Mar; 16(2):131-4. [PubMed] [Crossref]

5. Mokhlis GR, Matis BA, Cochran MA, Eckert GJ. A clinical evaluation of carbamide peroxide and hydrogen peroxide whitening agents during day- time use. J Am Dent Assoc. 2000 Sep; 131(9):1269-77. [PubMed] [Crossref]

6. Teixeira EC, Hara AT, Serra MC. Use of $37 \%$ carbamide peroxide in the walkingbleach technique: a case report. Quintessence Int. 2004 Feb; 35(2):97102. [PubMed]

7. Madison S, Walton R. Cervical root resorption following bleaching of endodonticallytreated teeth. J Endod. 1990 Dec;16(12):570-4. [PubMed] [Crossref]

8. Badole GP, Warhadpande MM, Bahadure RN, Badole SG. Aesthetic Rehabilitation of Discoloured Nonvital Anterior tooth with Carbamide Peroxide Bleaching: Case Series. J Clin Diagn Res. 2013 Dec; 7(12):3073-6. [PubMed] [Crossref]

9. Plotino G, Buono L, Grande NM, Pameijer CH, Somma F. Nonvital Tooth Bleaching: A Review of the Literature and Clinical Procedures. J Endod. 2008 Apr;34(4):394-407. [PubMed]

\section{[Crossref]}

10. Alqahtani MQ. Tooth-bleaching procedures and their controversial effects: A literature review. Saudi Dent J. 2014 Apr;26(2):33-46. [PubMed] [Crossref]

11. Srinivasan R, Bandyopadhyay TK, Bhagabati N, Jaya R. Aesthetic management of a discoloured non-vital immature maxillary central incisor. Med J Armed Forces India. 2015 Dec; 71(Suppl 2):S462-5. [PubMed] [Crossref]

12. Liebenberg WH. Intracoronal lightening of discolored pulpless teeth: a modified walking bleach technique. Quintessence Int. 1997 Dec; 28(12):771-7. [PubMed]

13. Dubal R, Porter RWJ. An update on discoloured teeth and bleaching part 2: mechanism of action of bleaching agents and management of discoloured teeth. Dental Update. 2018 Sep 2;45(8):698-710 [Crossref]

Please cite this article as: Georgieva I. Intracavity tooth bleaching in the aesthetic zone of maxilla using carbamide peroxide gel - case report. J of IMAB. 2020 Jul-Sep;26(3):3223-3225. DOI: https://doi.org/10.5272/jimab.2020263.3223

Address for correspondence:

Irena Georgieva

Department of Periodontology and Dental Implantology Dental Faculty, Medical University-Varna,

84, Tsar Osvoboditel Blvd., 9000 Varna, Bulgaria

e-mail: dr.irenageorgieva@mail.bg 